pathways that stimulate or suppress $\mathrm{GH}$ release in these two conditions may be alike, and may therefore be similarly modified by bromocriptine. Alternatively, a main site of action of bromocriptine may be the pituitary, where the cells may respond to the drug in the same way in anorexia nervosa as in the adenoma of the patient with acromegaly. In the obese patients bromocriptine did not alter the response to the oral glucose tolerance test, GH concentrations being neither raised nor lowered. Any initial $\mathrm{GH}$ release after bromocriptine might be short-lived, and might not occur with continuous administration.

The failure of bromocriptine to modify the $\mathrm{GH}$ response to insulin-induced hypoglycaemia is in keeping with the suggestion that this response is largely serotonergic, as it is partially inhibited by serotonin antagonists. ${ }^{16}$ Similar serotonergic mechanisms have been shown in the corticotrophin response to insulin hypoglycaemia, ${ }^{1-}$ and the rise in plasma 11-OHCS was also unaltered during bromocriptine treatment.

Prolactin concentrations were reduced during treatment in both groups of patients, the anorexic patients as a group having a higher concentration before treatment than the obese patients. The dose of $10 \mathrm{mg}$ bromocriptine daily was not only ineffective in reducing the weight of patients with refractory obesity, but the side effects were also more troublesome than those experienced by the patients with anorexia nervosa.

Although no significant weight changes occurred in the anorexic patients over a period of two weeks' treatment, the effect of bromocriptine on GH release suggests that the drug merits further consideration in this disorder. Amenorrhoea in anorexia nervosa, which precedes weight loss in many patients, ${ }^{4}$ might be related to hyperprolactinaemia. Such an association, together with the known effect of bromocriptine on hyperprolactinaemia, would justify further study in this type of patient, particularly if patients could be identified as anorexic before their abnormal eating habits and behaviour had become firmly established. Our findings, however, do not justify further use of the drug in obesity.

We thank our nursing, dietitian, and technician colleagues for help with this study, and Dr D B Horn for undertaking some of the assays in the department of clinical chemistry.

\section{References}

${ }^{1}$ Camanni, F, et al, fournal of Clinical Endocrinology and Metabolism, $1975,40,363$.

2 Thorner, M O, et al, British Medical fournal, 1975, 1, 299.

${ }^{3}$ Sachdev, Y, et al, Lancet, 1975, 2, 1164

Kanis, J A, et al, Quarterly fournal of Medicine, 1974, 43, 321.

${ }^{5}$ Hunter, W M, Friend, J A R, and Strong, J A, fournal of Endocrinology, 1966, 34, 139.

${ }^{6}$ Baird, J D, in Symposium on Anorexia and Obesity, p 83. Royal College of Physicians of Edinburgh, 1973.

${ }^{7}$ Beaumont, P J V, et al, Psychological Medicine, 1974, 4, 219.

${ }^{*}$ Franks, S, et al, Clinical Endocrinology, 1975, 4, 597.

9 Travaglini, P, et al, Acta Endocrinologica, 1976, 81, 252

10 Thorner, M O, et al, British Medical fournal, 1974, 2, 419.

${ }^{11}$ Hill, J B, and Kessler, G, Fournal of Laboratory and Clinical Medicine, 1961, 57, 970 .

12 Mattingly, D, fournal of Clinical Pathology, 1962, 15, 374.

13 Schalch, D S, Parker, M L, Nature, 1964, 103, 1141

${ }^{14}$ Hales, C N, and Randle, P, fournal of Biochemistry, 1963, 88, 137.

15 Reuter, A M, et al, International fournal of Nuclear Medicine and Biology, $1976,3,21$.

${ }^{16}$ Bivens, C H, Lebovitz, $\mathrm{H}$ E, and Feldman, J M, New England fournal of Medicine, 1973, 289, 236.

1: Plank, J W, Bivens, C H, and Feldman, J M, Fournal of Clinical Endocrinology and Metabolism, 1974, 38, 836.

\title{
Circulating immune complexes after repeated halothane anaesthesia
}

\author{
B D WILliams, N White, P L AMLOT, J SLANEY, P A TOSELAND
}

British Medical fournal, 1977, 2, 159-162

\section{Summary}

A patient developed hepatitis after receiving three halothane anaesthetics in 22 days. Twenty-four hours after the onset of jaundice she developed an acute serum sickness syndrome with polyarthralgia, proteinuria, and transient impairment of renal function. Serum concentrations of complement components $\mathrm{C1q}, \mathrm{C4}$, and

Royal Postgraduate Medical School, Hammersmith Hospital, London W12 0HS

B D WILLIAMS, MSC, MRCP, lecturer, department of immunology

National Hospital for Nervous Diseases, Queen Square, London WC1

N WHITE, BSC, MRCP, senior house officer

Guy's Hospital, London SE1 9RT

P L AMLOT, MB, MRCP, lecturer, department of medicine

J SLANEY, AIMLT, technician, department of medicine

P A TOSELAND, BSC, PHD, principal biochemist
C3 were substantially reduced, and immune complexes capable of activating the complement system via the classical pathway were present in the serum and synovial fluid. A metabolite of halothane was associated with these complexes. Fourteen months after exposure to halothane her lymphocytes were stimulated in vitro by this metabolite. The conditions under which stimulation occurred were unusual-namely, a $7 S$ fraction of the serum, presumably IgG, was necessary. Our results provide strong evidence that halothane may be immunogenic and that its immunogenicity is dependent on the noncovalent binding of one of its metabolites to plasma proteins.

\section{Introduction}

Although the incidence of jaundice after halothane anaesthesia is believed to be low,' there is continuing controversy whether a direct association exists between repeated exposure to halothane and postoperative hepatic necrosis. ${ }^{2}$ The mechanisms producing liver damage are not known, although it is widely held to be the result of a delayed hypersensitivity response to halothane or one of its metabolites. 
We recently had the opportunity to study a patient who developed severe liver damage and jaundice after receiving three anaesthetics with halothane. During her illness she also developed an acute serum sickness syndrome with polyarthritis, proteinuria, and transient impairment of renal function. The close time relationship between the administration of halothane and the appearance of features known to be associated with hypersensitivity led us to investigate whether these were produced by an allergic response to halothane.

\section{Case report}

A 59-year-old obese diabetic woman was referred with a lump in the right breast. Since 1962 she had been taking $0.2 \mathrm{mg}$ thyroxine daily, and during the previous two years chlorpropamide and phenformin. Results of preoperative liver function studies were normal. Frozen-section biopsy confirmed the presence of an infiltrating scirrhous carcinoma, and a modified radical mastectomy was performed. During the operation she received two units of blood. By the seventh day she had developed a wound haematoma, which became infected with Staphylococcus aureus. Despite flucloxacillin $250 \mathrm{mg}$ four times daily, necrosis of the skin flap occurred, and 19 days after the operation this area was excised. Three days later a skin graft was applied to the granulating wound bed. At each operation halothane was used as part of the anaesthetic.

Three days after the last anaesthetic the patient became unwell, complained of nausea, and vomited several times. She was also noted to be jaundiced and feverish. Liver function studies indicated hepatocellular damage rather than cholestasis-serum aspartate aminotransferase (SGOT) $568 \mathrm{U} / 1$ alkaline phosphatase $14 \mathrm{KAU} / 1 ; \gamma$-glutamyltranspeptidase $(\gamma$-GT) $235 \mathrm{U} / 1$ total bilirubin $100 \mu \mathrm{mol} / 1(5.8 \mathrm{mg} / 100 \mathrm{ml})$; direct bilirubin $58 \mu \mathrm{mol} / 1$ ( $3.4 \mathrm{mg}$ ! $100 \mathrm{ml}$ ) (normal values in our laboratory: SGOT $0-35 \mathrm{U} / \mathbf{1} ; \gamma-\mathrm{GT} 8-35 \mathrm{U} / \mathbf{1}$; alkaline phosphatase $0-15 \mathrm{KAU} / 1$; bilirubin $18 \mu \mathrm{mol} / 1(1.1 \mathrm{mg} / 100 \mathrm{ml}))-$ with a prolonged prothrombin time $(28 \mathrm{~s}$, normal $12 \mathrm{~s})$, which did not reverse with vitamin $\mathrm{K}$. There was no eosinophilia. Halothane-related hepatitis was diagnosed and she was treated with a low-protein diet and neomycin and lactulose by mouth. Her diabetes was controlled with soluble insulin. Next day' she had a painful, swollen right knee: the effusion was sterile and contained $320 \times 10^{3}$ white cells $/ 1\left(90^{\circ}\right.$, polymorphs $)$. Serum urate concentration was normal.

Over the next three days she complained of migratory arthralgia, although no more effusions appeared. During this period the blood urea concentration began to rise and protein was found in the urine. As these abnormalities resolved the serum sodium fell to $111 \mathrm{mmol}(\mathrm{mEq}) / 1$ (plasma osmolality $264 \mathrm{mmol}(\mathrm{mOsm}) / \mathrm{kg}$ ) and a trace of ankle oedema was noted. At this time the urinary sodium was $24 \mathrm{mmol}(\mathrm{mEq}) / 1$, urinary osmolality $206 \mathrm{mmol}$ $(\mathrm{mOsm}) / \mathrm{kg}$, and plasma cortisol $700 \mathrm{nmol} / 1(25 \mu \mathrm{g} / 100 \mathrm{ml})$. She made slow, subjective and biochemical recovery, and when discharged her liver function values were only mildly abnormal (SGOT $47 \mathrm{U} / 1 ; \gamma-G T 248 \mathrm{U} / 1$; prothrombin time $16 \mathrm{~s}$ ). Six months later liver function was normal.

With neither the passive haemagglutination assay nor radioimmunoassay was hepatitis $B$ antigen detected in the serum or synovial fluid. During the acute phase of the polyarthritis tests for rheumatoid factor in serum gave a positive result with the latex fixation test but a negative result with the Rose-Waaler test. Autoantibodies to thyroid microsomes and parietal cells were also present. The liver-kidney microsomal antibody was not found during the illness or in the convalescent period.

\section{Materials and methods}

Halothane was obtained from ICI Ltd, and trifluoroacetic acid from Sigma Ltd. Blood samples were allowed to clot at room temperature for 30 minutes. Serum was then separated and stored at $-70^{\circ} \mathrm{C}$ Synovial fluid samples were also stored at $-70^{\circ} \mathrm{C}$ until used.

For comparison, postoperative serum samples were taken from four control patients (A-D) who had received halothane as part of an anaesthetic. Samples were taken within four hours of completing the operation, and in one case (control A) a further sample was taken at 24 hours.

Fractionation of serum-Serum samples were fractionated on a $1.5 \times 90 \mathrm{~cm}$ G-200 Sephadex column that had been equilibrated with $0.01 \mathrm{M}$ phosphate-buffered saline. The first peak (19S), second peak $(7 S)$, and third peak (4S) fractions were pooled and concentrated back to the original sample volume. When appropriate the fractions were dialysed against either complement-fixing buffer or tissue culture medium.

Measurement of complement concentrations and detection of immune complexes-Concentrations of $\mathrm{Clq}, \mathrm{C} 4$, and $\mathrm{C} 3$ were determined by radial immunodiffusion against monospecific antisera. Immune complexes in serum and synovial fluid were detected by means of the $\mathrm{Clq}$ agarose precipitation test. ${ }^{3}$ The strength of the precipitation reaction was arbitrarily graded as ++ (precipitation visible at
18 hours), + (precipitation visible at 72 hours), and \pm (precipitate visible only after staining). The ability of the three column fractions to produce breakdown of $\mathrm{C} 3$ in normal human serum (NHS) was detected by incubation of the appropriate sample with an equal volume of NHS for 45 minutes at $37^{\circ} \mathrm{C}$, followed by crossed electrophoresis of the incubation mixture against monospecific anti-C3 antiserum. ${ }^{4}$ The incubation mixture was compared with two control mixtures: NHS incubated alone at $37 \mathrm{C}$, and NHS incubated with the fractions at $4^{\circ} \mathrm{C}$. In every instance, after 15 minutes of incubation edetic acid was added to a final concentration of $0.01 \mathrm{~mol} / 1(292 \mathrm{mg}$ $100 \mathrm{ml}$ ) to reduce the spontaneous breakdown of C3. The capacity of these fractions to activate the classical pathway of complement was also assessed by incubation with normal guinea-pig and C4-deficient guinea-pig serum. After incubation the mixture was subjected to electrophoresis and the $\mathrm{C} 3$ identified with a monospecific antiserum. Similar controls to those outlined above were included.

Lymphocyte culture-Venous blood was collected into heparin at a final concentration of $10 \times 10^{3} \mathrm{U} / 1$ and separated on a Ficoll-Triosil gradient. Lymphocytes were cultured as described previously, except that $10^{9} \mathrm{cells} / \mathrm{l}$ were used for each experiment, and these were supplemented with either $15 \%$ normal $\mathrm{AB}$ serum or the patient's serum or one of the three Sephadex fractions. ${ }^{5}$ Results were expressed in $\mathrm{cpm}$ as the mean of triplicate cultures.

Gas-liquid chromatography-Equal quantities of high-purity benzene (glass-distilled analytical grade reagent) and serum, synovial fluid, or serum fractions were mixed on a rotamixer for five minutes and then centrifuged. A 3-: 2 l sample of a benzene solution was then injected into a $183 \times 0.4 \mathrm{~cm}$ glass column of Chromosorb 101 operated at $120^{\circ} \mathrm{C}$ by means of electron-capture detection on a HewlettPackard 5710.

\section{Results}

Figure 1 summarises the patient's clinical course after the second operation. Jaundice and abnormal liver function were seen three days after the last anaesthetic; the effusion and arthralgia appeared next day and coincided with the increase in blood urea and development of proteinuria. Low serum complement concentrations were found on day 7 , and the concentrations of $\mathrm{Clq}, \mathrm{C} 3$, and $\mathrm{C} 4$ remained low for several days after the joint symptoms had disappeared. Clq precipitins were present in the synovial fluid on day 7 and in the serum and synovial fluid on day 10 . They were not detected once the patient's symptoms had disappeared. The material precipitating with $\mathrm{Clq}$ was further characterised by fractionation on G-200 Sephadex.
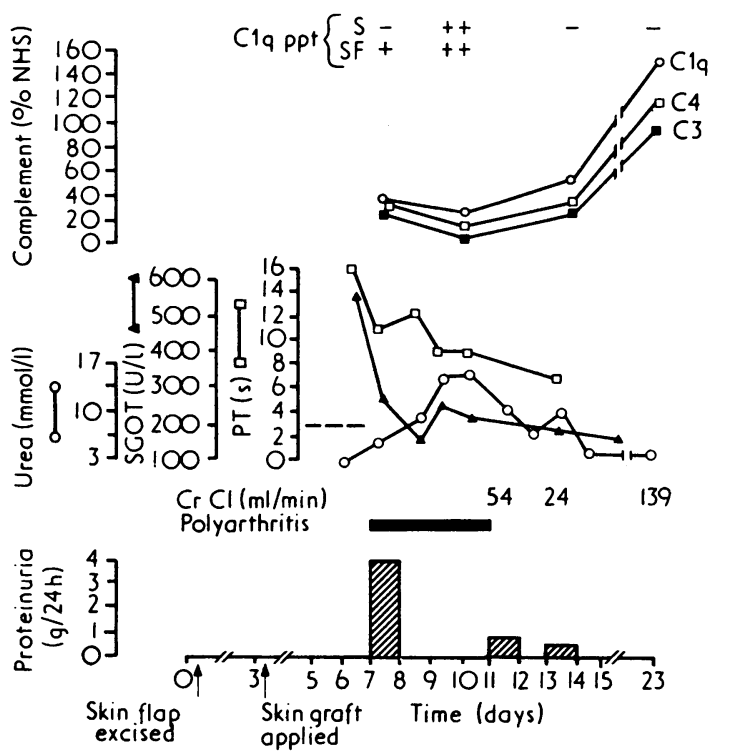

FIG 1-Patient's clinical course after second operation. $\mathrm{S}=$ Serum. $\mathrm{SF}=$ Synovial fluid. $\mathrm{Clq} \mathrm{ppt}=\mathrm{Clq}$ precipitins PT $=$ Prothrombin time ( -- difference from normal value). $\mathrm{Cr} \mathbf{C l}=$ Creatinine clearance. Conversion: SI to traditional units-Urea: $1 \mathrm{mmol} / 1 \approx 6 \mathrm{mg} /$ $100 \mathrm{ml}$. 
This material, in both serum and synovial fluid, was confined to fractions of large molecular weight (table I). These fractions were also the most efficient in producing $\mathrm{C} 3$ conversion in NHS. Although they could convert $\mathrm{C} 3$ in normal guinea-pig serum, they were unable to convert C3 in C4-deficient guinea-pig serum. Postoperative serum and normal serum, fractionated under identical conditions, did not initiate $\mathrm{C} 3$ conversion or precipitate with $\mathrm{Clq}$.

TABLE I-C3 conversion produced by serum and synovial fluid fractions on days 7-10 after second operation

\begin{tabular}{|c|c|c|c|c|}
\hline Sample & $\underset{\text { precipitins }}{\mathrm{Clq}}$ & $\underset{\substack{\text { C3 } \\
\text { conversion } \\
\left(\%_{1}\right)}}{ }$ & NGPS* & C4D \\
\hline $\begin{array}{l}\text { Day 7, serum (peak 1) . } \\
\text { Day 7, synovial fluid (peak 1) } \\
\text { Day 10, serum (peak 1) . } \\
\text { Day 10, synovial fluid (peak 1). } \\
\text { Normal serum (peak 1)... }\end{array}$ & $\begin{array}{l}- \\
+ \\
++ \\
++\end{array}$ & $\begin{array}{r}10 \\
13 \\
24 \\
23 \\
4\end{array}$ & $\begin{array}{l}+ \\
+ \\
++ \\
++\end{array}$ & $\begin{array}{l}\overline{-} \\
\overline{-} \\
\overline{-}\end{array}$ \\
\hline
\end{tabular}

NGPS $=$ Normal guinea-pig serum .

$\mathrm{C} 4 \mathrm{D}=\mathrm{C} 4$-deficient guinea-pig serum

*Conversion of $\mathrm{C} 3$ in normal guinea-pig serum graded $++>50 \% ;+20-50 \%$;

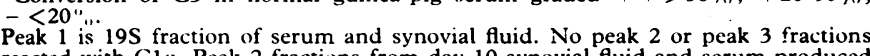
reacted with $\mathrm{Cl}$. Peak 2 fractions from day 10 synovial fluid and serum produced mall amount of $\mathrm{C} 3$ conversion; other peak 2 fractions and all peak 3 fractions failed to convert $\mathrm{C} 3$.

The concentration of halothane in serum samples taken at various times after operation was measured with gas-liquid chromatography. Although the benzene solution was used primarily as a solvent, the presence of two trace contaminants allowed halothane to be identified from its position relative to one of these. The benzene peak was used as an internal standard when measuring large quantities of halothane, but when the concentration of halothane was small one of the benzene contaminants was used as the standard. Although pure halothane produced a single peak, serum samples from the patient and controls contained an additional peak (substance X) (fig 2). By exposing halothane to sunlight we showed that this additional peak was derived from halothane: after several days of exposure a small amount of substance $\mathrm{X}$ had been produced. Both halothane and substance $\mathrm{X}$ were present in the patient's serum during the early stages of her illness, although by the 14th postoperative day only halothane was detected (table II) Trifluoroacetic acid could not be detected by gas-liquid chromatography.

The distribution of halothane and substance $\mathrm{X}$ in fractionated serum and synovial fluid is summarised in table III. In postoperative serum from control $B$, substance $X$ was found in all three peaks, with the largest amount in peak 3. Halothane, although present in unfractionated serum, was not found in any of the three peaks after fractionation. In the patient's serum and synovial fluid substance $\mathrm{X}$ was virtually

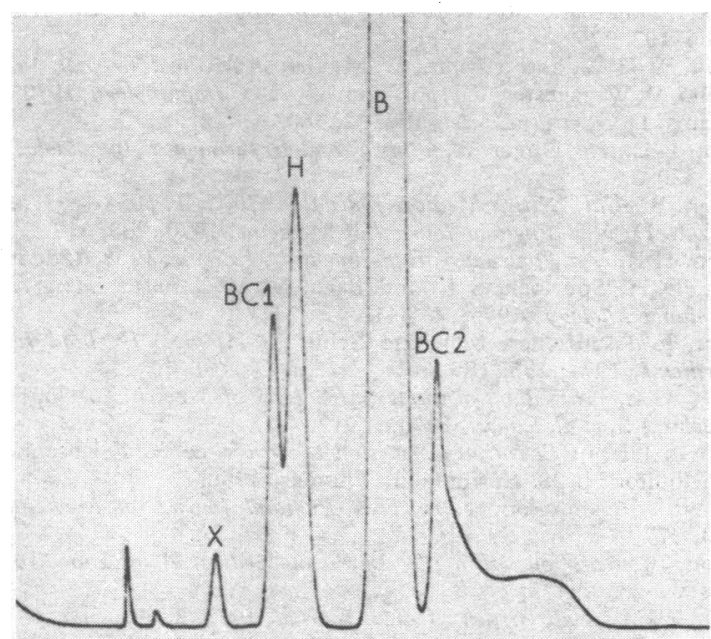

FIG 2-Gas-liquid chromatogram profile of benzene extracted from postoperative serum. $X=$ Substance $X$. $\mathrm{BC} 1$ and $\mathrm{BC} 2=$ Benzene contaminants. $\mathrm{H}=$ Halothane $\mathbf{B}=$ Benzene.
TABLE II-Presence of halothane and halothane metabolite (substance $X$ ) $i^{\text {n }}$ postoperative serum from four controls and serum and synovial fluid from patien ${ }^{t}$

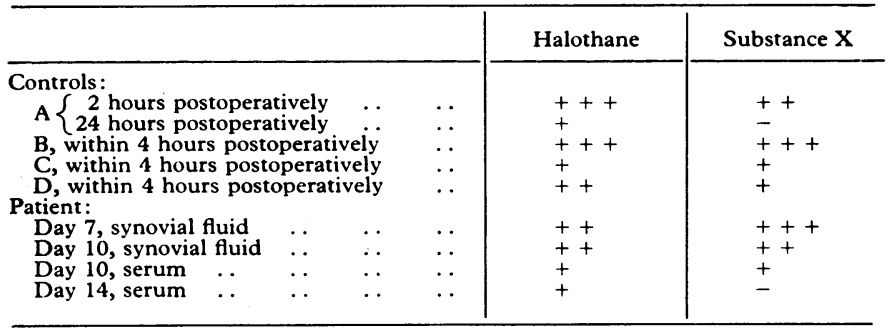

TABLE III-Distribution of substance $X$ in serum and synovial fluid from patient fractionated on G-200 Sephadex. Distribution in serum from control $B$ given for comparison

\begin{tabular}{|c|c|c|c|c|}
\hline & & Peak 1 & Peak 2 & Peak 3 \\
\hline $\begin{array}{l}\text { Serum, day } 7 \\
\text { Synovial fluid, day } 7\end{array} \begin{array}{l}\ldots \\
\text { Serum, day } 10 \\
\text { Synovial fluid, day } 10 \\
\text { Control serum }\end{array}$ & $\begin{array}{l}\cdots \\
\cdots \\
\cdots \\
\cdots\end{array}$ & $\begin{array}{l}+++ \\
+++^{*} \\
++^{*} \\
+++^{*} \\
+\end{array}$ & $\begin{array}{l}- \\
+ \\
\overline{+} \\
+\end{array}$ & $\begin{array}{l}-* \\
- \\
- \\
+ \\
++\end{array}$ \\
\hline
\end{tabular}

*Trace amounts of halothane.

confined to peak 1 , with only trace amounts in the second peak. Its distribution was similar to the distribution of the $\mathrm{Clq}$ reactive material and the $\mathrm{C} 3$ converting activity.

Since substance $\mathrm{X}$ was associated with putative immune complex activity, fractionated postoperative serum containing this substance but free from halothane was used as the source of antigen in the in-vitro lymphocyte cultures. This test was first carried out 14 months after the radical mastectomy and repeated two months later. Stimulation with purified protein derivative of tuberculin occurred in both autologous and heterologous serum, whereas substance $\mathrm{X}$ stimulated the cultures only when autologous serum was present (table IV).

TABLE IV-Stimulation of patients' lymphocytes by substance $X$ in presence of autologous and heterologous serum. Results expressed as cpm ${ }^{3} \mathrm{H}-T d R \pm S E$

\begin{tabular}{|c|c|c|c|c|c|}
\hline & \multirow{2}{*}{ No antigen } & \multicolumn{3}{|c|}{ G-200 fractions* } & \multirow{2}{*}{$\begin{array}{l}\text { PPD } \\
(5 \mu \mathrm{g})\end{array}$} \\
\hline & & Peak 1 & Peak 2 & Peak 3 & \\
\hline $\begin{array}{l}\text { Normal AB serum } \\
\text { Autologous serum }+\end{array}$ & $\begin{array}{l}658 \pm 85 \\
904 \pm 117\end{array}$ & $\begin{array}{l}623+31 \\
892 \pm 83\end{array}$ & $\begin{array}{r}618+120 \\
7165+162\end{array}$ & \begin{tabular}{|c|c|}
641 & 68 \\
1294 & 194 \\
\end{tabular} & $\begin{array}{ll}18415 & \pm 786 \\
35788 & \pm 1588\end{array}$ \\
\hline
\end{tabular}

PPD $=$ Purified protein derivative of tuberculin.

*These fractions of postoperative serum from control fractionated on G-200 Sephadex. Maximum stimulation seen when fractions used at dilution of $1 / 10$. tSerum taken 14 months after last exposure to halothane.

Stimulation was greatest with peak 2 , although appreciable stimulation also occurred with peak 3. The degree of lymphocyte stimulation also varied with the concentration of antigen added to the culture. Control cultures containing the-patient's serum, antigen, and lymphocytes from a normal donor did not show any stimulation. The factor

TABLE V-Stimulation of patient's lymphocytes by G-200 fractions of autologous serum. Results expressed as cpm ${ }^{3} H-T d R \pm S E$

\begin{tabular}{|c|c|c|c|c|}
\hline \multirow{2}{*}{\multicolumn{2}{|c|}{$\begin{array}{l}\text { G-200 fractions of } \\
\text { control postoperative } \\
\text { serum* }\end{array}$}} & \multicolumn{3}{|c|}{ G-200 fractions of patient's serum $\dagger$} \\
\hline & & Peak 1 & Peak 2 & Peak 3 \\
\hline $\begin{array}{l}\text { Peak } 1 \\
\text { Peak } 2 \\
\text { Peak } 3\end{array}$ & $\begin{array}{ll} & \\
\cdots & \end{array}$ & $\begin{array}{l}155 \pm 23 \\
216 \pm 28 \\
304 \pm 31\end{array}$ & $\begin{array}{l}241 \pm 27 \\
292 \pm 34 \\
991 \pm 69\end{array}$ & $\begin{array}{l}433 \pm 97 \\
369 \pm 42\end{array}$ \\
\hline
\end{tabular}

* Substance $X$ present in moderate amounts in peak 3 and trace amounts in peaks 1 and 2 . Halothane was not found in any peak.
+ Fractions of serum taken 16 months after last exposure to halothane. 
in the patient's serum needed to produce in-vitro lymphocyte stimulation was localised to the $7 \mathrm{~S}$-immunoglobulin-containing fractions (table V).

\section{Discussion}

When other possible causes of postoperative jaundice have been excluded there remains a group of patients-often female, obese, and with a tendency to develop organ-specific autoimmune disease $^{6}$ - who have been exposed to halothane. Multiple exposures, particularly within four weeks, appear to increase the incidence of hepatitis and shorten the interval between exposure and the development of jaundice. Our patient satisfied these criteria, and in the absence of a safe, specific diagnostic test for halothane hepatitis we presume that her jaundice and liver damage were related to multiple exposures to halothane.

Rashes, fever, and arthralgia, although uncommon, have been described after exposure to halothane. ${ }^{6}$ - Our patient was unusual in that the symptoms and signs known to be associated with a "hypersensitivity phenomenon" were particularly prominent features of her illness. The pattern of organ involvement also suggested that damage may have been produced by the deposition in the tissues of circulating antigen-antibody complexes. The presence in the serum and synovial fluid of large molecules that reacted with $\mathrm{Clq}$ and activated the complement system via the classical pathway provides good supportive evidence. Moreover, the changes in concentrations of complement components were probably produced by in-vivo activation of the complement system and not through any effects that liver damage may have had on the synthesis of these proteins, for experiments indicate that $\mathrm{Cl}$ synthesis occurs almost exclusively in the small and large intestines. ${ }^{9}$ The pattern of complement activation and the requirement for $\mathrm{C} 4$ to produce in-vitro conversion of guinea-pig C3 also preclude any important role of alternative pathway activators such as endotoxin.

The antigen present in the complexes could have arisen from several different sources. Hepatitis B antigen could be one possibility, since infections with this virus are associated with a similar clinical syndrome. ${ }^{10}$ This explanation is unlikely in view of the short interval between transfusion and the appearance of jaundice and the failure to detect the antigen with two sensitive assays. Alternatively the antigen may have been derived from halothane. The distribution of substance $\mathrm{X}$ in the patient's serum and synovial fluid and its association with large molecules possessing activities known to be associated with immune complexes supports this explanation. The formation of a complex between protein-bound substance $\mathrm{X}$ and antibody would also account for the differences in distribution of substance $\mathrm{X}$ between the patient's serum and control postoperative serum.

Unlike halothane, which binds poorly if at all to protein, substance $\mathrm{X}$ binds avidly, and it was found in every peak of fractionated serum. Binding to a carrier protein is necessary before a small molecule can become immunogenic: indeed, covalent binding to protein has been considered to be obligatory before incriminating halothane as the cause of a hypersensitivity reaction. ${ }^{11}$ Although substance $\mathrm{X}$ binds to the serum proteins, it does so through non-covalent forces, since it can be readily extracted from the serum with benzene. Barbitone is another drug that binds to the serum proteins through non-covalent forces. ${ }^{12}$ Non-covalent interactions can produce complexes that may sensitise the patient, and perhaps the best known example in which sensitisation occurs is Sedormid purpura. ${ }^{13}$ This drug binds non-covalently to the platelet surface, forming a complex that then induces the formation of antibody.

Of the numerous attempts to demonstrate cell-mediated immunity to halothane $e^{1+16}$ or its major metabolite trifluoroacetate, ${ }^{17}$ only one has been successful. ${ }^{14}$ The sensitisation shown in that study, however, was transient and persisted for only a few months. Substance $\mathrm{X}$ could produce lymphocyte stimulation in vitro, and this effect was first observed 14 months after the last exposure to halothane. Lymphocyte stimulation varied with antigen concentration and was unusual in that a $7 \mathrm{~S}$ fraction of the patient's serum was required. One possible explanation for these findings is that complexes of antigen and antibody are produced in culture and that complexes formed at different antigen : antibody ratios stimulated the lymphocytes with different degrees of efficiency. Lack of stimulation in control cultures indicated that the stimulation seen with the patient's cells was not due to a non-specific mitogenic effect of these complexes. We do not know which population of cells responded in culture, but the responding cells may have formed part of the antigen-specific B-cell pool.

Many factors may have contributed to the acute serum sickness syndrome in our patient. She is unlikely to have developed this complication because she metabolised halothane in different ways, since substance $\mathrm{X}$ was also found in other patients who had received this agent. The high concentrations of substance $\mathrm{X}$ in her serum, however, could reflect a mechanism leading to the more efficient production of substance $\mathrm{X}$ or an impairment in its clearance once it had become bound to protein. The presence of an autoimmune diathesis may also have been a contributory factor. The identity of substance $\mathrm{X}$ is not known, except that it is not trifluoroacetate. Nor is it known whether it is a single metabolite of halothane or several metabolites identifiable as a single peak on gas-liquid chromatography.

In a subject that has generated so much controversy it would be unwise to draw too many conclusions from observations made in a single study. Although our results show that a metabolite of halothane can become antigenic after binding to protein, it does not follow that the liver damage seen in patients repeatedly exposed to halothane is produced by an allergic response to this metabolite. If this metabolite were bound to the glycoproteins of the hepatic cells, however, then these cells would be susceptible to damage by two separate antibody-dependent mechanisms. Binding of specific antibody could produce complementmediated membrane lysis, or the cells could be damaged by an antibody-dependent cell-mediated cytotoxic mechanism. ${ }^{1 *}$ The detection of such antibodies could therefore be valuable in determining which patients had become sensitised and whether they might be at risk from repeated halothane anaesthesia.

We thank Professor A P Waterson, of the Royal Postgraduate Medical School, and Dr D S Dane, of the Middlesex Hospital, for performing the assays for hepatitis B antigen.

\section{References}

1 National Halothane Study, fournal of the American Medical Association, 1966, 197, 775.

2 Inman, W H W, and Mushin, W M, British Medical fournal, 1974, 1, 5

${ }^{3}$ Agnello, V, Winchester, R J, and Kunkel, H G, Immunology, 1970, 19, 909.

4 Williams, D G, et al, Lancet, 1972, 2, 360.

5 Amlot, P L, and Unger, A, Clinical and Experimental Immunology, 1976, 26, 520 .

${ }^{6}$ Walton, B, et al, British Medical fournal, 1976, 1, 1171.

${ }^{7}$ Doniach, D, New England fournal of Medicine, 1970, 283, 312.

${ }^{8}$ Colten, H R, et al, fournal of Experimental Medicine, 1968, 128, 595.

${ }^{\circ}$ Bring, D H, Spurlock, S E, and Bern, M M, Clinical Immunology and Immunopathology, 1975, 4, 341 .

10 Alpert, E, Isselbacher, K J, and Schur, P H, New England fournal of Medicine, 1971, 285, 185.

11 Davies, G E, Proceedings of the Royal Society of Medicine, 1973, 66, 55.

12 Cameron, J S, et al, Lancet, 1970, 1, 912.

13 Ackroyd, J F, in Sensitivity Reaction to Drugs, ed M L Rosenheim and R Moulton, p 28. Springfield, Thomas, 1958.

14 Paronetto, F, and Popper, H, New England fournal of Medicine, 1970, 283, 277.

15 Walton, B, et al, fournal of the American Medical Association, 1973, 225, 494.

${ }_{16}$ Moult, P J A, et al, British Medical fournal, 1975, 2, 69.

17 Walton, B, et al, Anesthesiology, 1976, 44, 391.

18 MacLennan, I C M, Loewi, G, and Howard, A, Immunology, 1969, 17, 897. 